Biochem. Lett, Vol. 6, PP. 1 -21 (2010)

\title{
INTERLEUKIN-4 (IL-4) AND \\ INTERLEUKIN-4 RECEPTOR ALPHA \\ CHAIN (IL-4Ra) GENE \\ POLYMORPHISMS IN EGYPTIAN \\ RHEUMATIC ARTHRITIS PATIENTS
}

\author{
Faten Z. Mohamed ${ }^{(1)}$; Yousri M. Mussien ${ }^{(2)}$ \\ and Eman F. Basiony ${ }^{(3)}$ \\ ${ }^{1}$ Biochemistry Division, Dept. of Chemistry, Faculty of \\ Science, Zagazig University; ${ }^{2}$ Faculty of Medicine, Zagazig \\ University, Egypt.
}

\begin{abstract}
ABSRACT
Rheumatoid arthritis (RA) is considered a Th1-driven disease. Interleukin 4 (IL-4) binds to its receptor, promoting Th2 differentiation and limiting Th1 responses, but its role in the pathogenesis of $R A$ is conflicting. Objective: to evaluate the occurrence of variants of interleukin-4 (IL-4) and Interleukin-4 Receptor Alpha chain (IL-4 RA) gene in patients with rheumatoid arthritis and their possible contribution to disease severity. Methods: We analyzed 2 polymorphisms of the IL 4 gene and 2 polymorphisms of IL-4 RA in patients with $R A$ and in a control population, as well as measuring serum $R F$ as a disease severity parameter. Results: The IL-4 -590 TT genotype $(P<0.001)$ and The IL4 $-590 T$ allele (OR 2.84, 95\% CI 1.0-8.77, $p=0.03$ ) were significantly more frequent in patients with $R A$ than in controls, this is similar for $I L-4 V N T R$ RP1/RP1 genotype $(P<0.001)$ and IL-4 RP1 allele (OR 2.91 CI 0.9210.23, $P=0.04)$. Higher frequency of $I L-4 R A I 50 V$ genotypes $(P=$ $0.02)$ in $R A$ patients compared with controls were also found. Nevertheless, the more severe form of $R A$ is observed in patients carrying the IL-4 -590 $T$ allele as compared with homozygous patients. The IL-4RA Q576 allele and IL-4RA V50 allele were significantly associated with the sever form of $R A$. Conclusion: The IL-4 -590 C/T, IL-4 VNTR in intron-3 and IL-4Ra I50V
\end{abstract}


polymorphism were associated with $R A$ susceptibility in Egyptian population. IL-4R $\alpha$ I50V and IL-4R $\alpha$ Q576R polymorphisms may be may be a genetic risk factor for $R A$ severity.

\section{INTRODUCTION}

Rheumatoid arthritis (RA) is a systemic inflammatory polyarthritis that affects $\quad 0.5-1 \%$ of the general population with high personal, social, and economic costs. It is a multifactorial disease, with genetic and environmental factors contributing to the pathogenesis ${ }^{(\mathbf{1})}$.

It is considered that RA is orchestrated by Th1 CD4+ cells that stimulate monocytes, macrophages, synovial fibroblasts, and other cells to produce cytokines such as tumor necrosis factor- $\alpha$ (TNF- $\alpha$ ), interleukin-1 (IL-1), IL-6, IL-15, IL-17, and metalloproteinases that produce tissue damage (2). In response to this proinflammatory reaction, anti-inflammatory mechanisms are activated in an attempt to control the autoreactivity. These mechanisms include the production of IL-10, IL-13, IL-4, and transforming growth factor- $\beta$, as well as antagonists of the mediators of inflammation such as the IL-1 receptor antagonist (IL-1Ra) and soluble receptors of TNF- $\alpha{ }^{(3)}$.

Interleukin-4 (IL-4) is produced by Th2 cells, basophils, eosinophils, and mastocytes and promotes the change of immunoglobulin production of B cells from IgM to IgE and IgG4 (4). It has stimulatory and inhibitory effects, inducing differentiation of Th0 to Th2 cells and among its anti-inflammatory processes are down regulation of proinflammatory cytokines such as TNF- $\alpha$, IL-1 $\beta$, IL-6, and interferon- $\gamma$ (IFN- $\gamma$ ), inhibition of the proliferation of fibroblastic cells of the articular synovium, and diminution of bone resorption (5). It has been established that synovial concentrations of IL-4 are low or absent in patients with RA ${ }^{(6)}$.

IL-4 exerts its biological activity by binding to the target cell receptor IL-4R (7). IL-4R is composed of two subunits: an $\alpha$ subunit that bind IL-4 and tranduces its growth promoting and transcription activating functions ${ }^{(8)}$ and a $\gamma$ subunit that is common to several cytokine receptors and amplifies signaling of the $\alpha$ subunit ${ }^{(9)}$. 
The gene for IL-4 has been mapped to the q arm (q23-31) of chromosome $5^{(11)}$. A functional polymorphism representing C-to-T substitution at position -590 has been recently described in the promoter region of IL-4 ${ }^{(\mathbf{1 0})}$. Another polymorphism has been located in the third intron, and is composed of a variable number of tandem repeats (VNTR) of a 70-bp ${ }^{(\mathbf{1 1})}$.

IL4RA is located at the short arm of chromosome 16p12.1. Several polymorphisms have been described in the codifying and in the non-codifying regions of the gene ${ }^{(\mathbf{1 5})}$. It has been established that polymorphisms located in the +148 codifying region (transition $\mathrm{A} / \mathrm{G}$, Ile50Val) of the extracellular domain ${ }^{(\mathbf{1 6})}$ and in the +1902 codifying region (transition $\mathrm{A} / \mathrm{G}, \mathrm{Gln} 576 \mathrm{Arg}$ (Q576R) )of the intracellular domain affect the binding of its ligand or the intracellular signaling, respectively ${ }^{(\mathbf{1 2})}$

In this study we tested the allelic distribution of these four polymorphisms among RA patients and investigated their involvement with RA severity.

\section{Subjects \& METHODS * Patients and controls:}

The study included 90 patients with rheumatoid arthritis (95.56\%women) with a mean age of $(47.75 \pm 9)$ years and 20 healthy controls (70\%women) with a mean age of $(46.68 \pm 6)$ years. The diagnosis of RA was conformed to the American college of rheumatology criteria ${ }^{(13)}$.

Patients were recruited from the outpatients and inpatients population of rheumatology and rehabilitation department, Zagazig university hospital, Elsharqia region, Egypt. All the patients and healthy individuals gave their written consent before blood sample collection.

Subjects enrolled in the study underwent routine biochemical blood analysis. X-rays of wrists, hands and feet were obtained in all patients. The evaluation of subjects included physical examination with particular focus on the pattern of joint involvement, the presence of nodules and other extra-articular features. 
Disease severity parameters were determined on the basis of defined parameters and a global physician's assessment. Rheumatoid factor (RF) titres were measured from serum samples by latex agglutination (Humantex RF, Germany). Titers $\geq 20 \mathrm{IU} / \mathrm{ml}$ were considered positive, the mean values were used.

\section{Genotyping:}

Subjects were genotyped for IL-4 promoter single nucleotide polymorphism at position -590 (14) by PCR-RFLP using 2 allelespecific primers A (forward) and B (reverse), respectively (Bio Basic Inc., Ontario, Canada). The primer sequences used for the IL-4 promoter SNP CT at Position -590 were as follows: 5'ACTAGGCCTCACCTGATACG- 3' (forward primer) and 5'GTTGTAATGCAGTCCTCCTG-3' (reverse primer).

PCR was performed in a final volume of $25 \mu \mathrm{L}$ containing $7 \mu \mathrm{L}$ of sterile deionized water, $5 \mu \mathrm{L}$ of genomic DNA, $0.5 \mu \mathrm{L}$ of each primer, and a $12.5 \mu \mathrm{L}$ of $2 \mathrm{X}$ PCR Master Mix (Bioron, Ludwigshafen am Rhein, Germany). The amplification was carried out using a PTC-100 thermal cycler (MJ Research, Inc., Watertown, Massachusetts, USA) according to the following protocol: Denaturation at $95 \mathrm{C}^{\circ}$ for 0.5 minute, Annealing at $57 \mathrm{C}^{\circ}$ for 0.5 minutes, Extention at $77 \mathrm{C}^{\circ}$ for 0.5 minutes with 32 cycles. Digestion was performed with $1 \mu \mathrm{L}$ Bsm F1 restriction enzyme (fermentas, Germany) in a total volume $30 \mu \mathrm{L}$ that contain $10 \mu \mathrm{L}$ of PCR products and $2 \mu \mathrm{L}$ of $10 \mathrm{X}$ Fast Digest Green buffer and $17 \mu \mathrm{L}$ of nuclease free water. The components were mixed gently and incubated at $37 \mathrm{C}^{\circ}$ in a heat block for $5 \mathrm{~min}$. Digestion yielded 252 bp for $\mathrm{T}$ allele and $192+60 \mathrm{bp}$ fragments for $\mathrm{C}$ allele. The products were then stored at $4 \mathrm{C}^{\mathrm{o}}$ until use. The digested products were analyzed on 3\% agarose gels stained with ethidium bromide and $50 \mathrm{bp}$ Marker.

Subjects were also genotyped for IL-4 VNTR ( 70 bp repeat in intron 3) by PCR-RFLP (11) using the forward primers 5'AGGCTGAAAGCGGGAAAGC-3' and reverse primers 5'CTGTTCACCTCAACTGCTCC-3' (Bio Basic Inc., Ontario, Canada).PCR protocol: Denaturation at $95 \mathrm{C}^{\circ}$ for 0.5 minute, 
Annealing at $60 \mathrm{C}^{\circ}$ for 0.7 minutes, Extension at $72 \mathrm{C}^{\circ}$ for 0.7 minute with 30 cycles. PCR products yields $183 \mathrm{bp}$ fragment for RP1 allele and $253 \mathrm{bp}$ fragment for RP2 allele. PCR products were directly analyzed on $2 \%$ agarose gels stained with ethidium bromide using 100 bp Marker, and each allele was recognized according to its size.

Subjects were genotyped for IL-4 Receptor gene $\alpha$ chain I50V single nucleotide polymorphism of the +148 codifying region (Ile50Val) by PCR-RFLP (16). The region surrounding the polymorphism was amplified with the following forward primers 5 'GGC AGG TGT GAG GAG CAT CC-3' and reverse primer 5'-GCC TCC GTT GTT CTC AGG GA-3' (Bio Basic Inc., Ontario, Canada). PCR was performed in a final volume of $25 \mu \mathrm{L}$ containing 7 $\mu \mathrm{L}$ of sterile deionized water, $5 \mu \mathrm{L}$ of genomic DNA, $0.5 \mu \mathrm{L}$ of each primer, and a $12.5 \mu \mathrm{L}$ of $2 \mathrm{X}$ PCR Master Mix (Bioron, Ludwigshafen am Rhein, Germany). The amplification was carried out using a PTC-100 thermal cycler (MJ Research, Inc., Watertown, Massachusetts, USA) at $938 \mathrm{C}^{\circ}$ for $5 \mathrm{~min}$, followed by 36 cycles at $938 \mathrm{C}^{\circ}$ for $60 \mathrm{sec}$, at $608 \mathrm{C}^{\circ}$ for $60 \mathrm{sec}$, and $728 \mathrm{C}^{\circ}$ for $60 \mathrm{sec}$. Digestion of 273 bp-amplified product with RsaI (fermentas, Germany) yielded 273 bp for I allele and 254-bp fragment when V allele was present. The PCR products were separated on $2 \%$ agarose gels stained with ethidium bromide using $100 \mathrm{bp}$ Marker.

Subjects were genotyped either for IL-4 Receptor gene $\alpha$ chain single nucleotide polymorphism at position 1902 (codon 576) A/G transition (Q576R ) by PCR-RFLP ${ }^{(17)}$ using forward primers 5 '-GCC CCC ACC AGT GGC TAC C-3' and reverse primers 5'-GCC TTG TAA CCA GCC TCT CCT-3'(Bio Basic Inc., Ontario, Canada).PCR conditions as following, Denaturaion at $94 \mathrm{C}^{\circ}$ for 0.5 min, Annealing at $55 \mathrm{C}^{\circ}$ for $0.5 \mathrm{~min}$, Extension at $72 \mathrm{C}^{\circ}$ for $0.5 \mathrm{~min}$ with 30 cycles. Digestion of 123 bp-amplified product with Msp1(fermentas, Germany) yielded $107+16$ bp for Q (A) allele and $89+18+16$ bp fragment for $R(G)$ allele. The products were then stored at $4 \mathrm{C}^{\mathrm{o}}$ until use. The PCR products were separated on $3 \%$ agarose gels and visualized under ultraviolet illumination and stained with $0.4 \mathrm{mgL}$ ethidium bromide. The agarose concentration and DNA 
molecular weight markers for each genotyping were adapted to the size of the expected DNA products.

\section{Statistical analysis:}

All results were analyzed by SPSS software (version 14) ${ }^{(18)}$. Results of the gene polymorphism studies were analyzed by comparison of allele frequencies (number of copies of a specific allele divided by the total number of alleles in the group) and carriage rates (number of individuals with at least 1 copy of a specific allele divided by the total number of individuals within the group) were calculated in the RA and control groups. Chi-square test was used for comparisons of frequencies between RA patients and healthy controls. Odds ratios (OR) were calculated for disease susceptibility in carriers of specific alleles. The 95\% confidence intervals (CI) for the OR were also calculated. A P-value $<0.05$ was considered to be statistically significant. RF titres as a disease severity parameter were expressed as mean \pm SD. Comparison of mean values of studied variables among different groups was done using ANOVA test. 
Interleukin-4 Gene polymorphism in Rheumatic Arthriits Patients

RESULTS

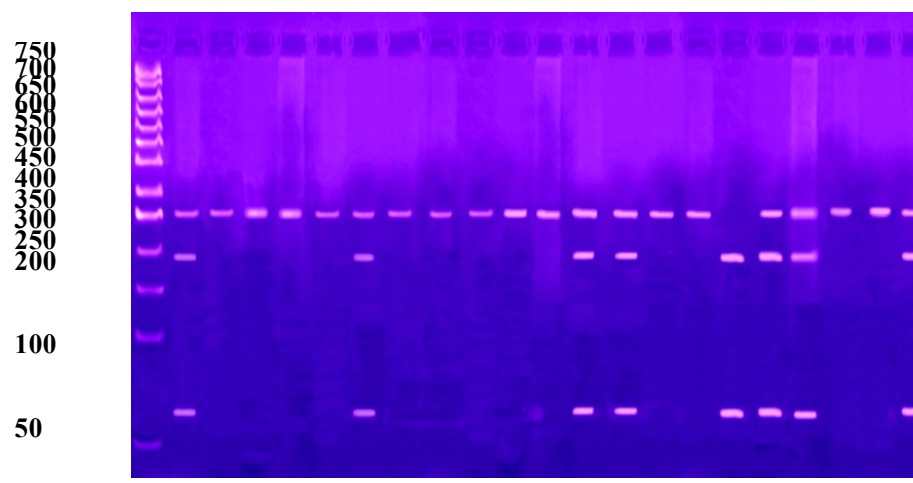

252 bp

192 bp

Fig (1): Rheumatoid Arthritis patients

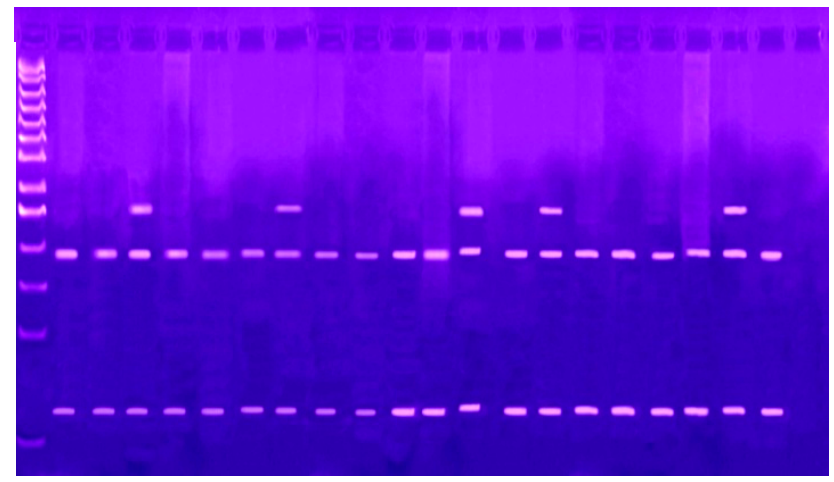

252 bp

192 bp

$60 \mathrm{bp}$

Fig (2): Controls

Fig (1), Fig (2): Agarose gel electrophoresis detection for IL-4 promoter single nucleotide polymorphism at position -590 for both RA patients and controls showing lanes of $252 \mathrm{bp}$ fragment for TT homozygous genotype, $252+192+60 \mathrm{bp}$ fragments for CT heterozygous genotype and lanes of $192+60$ for CC genotype (50 bp Marker). 


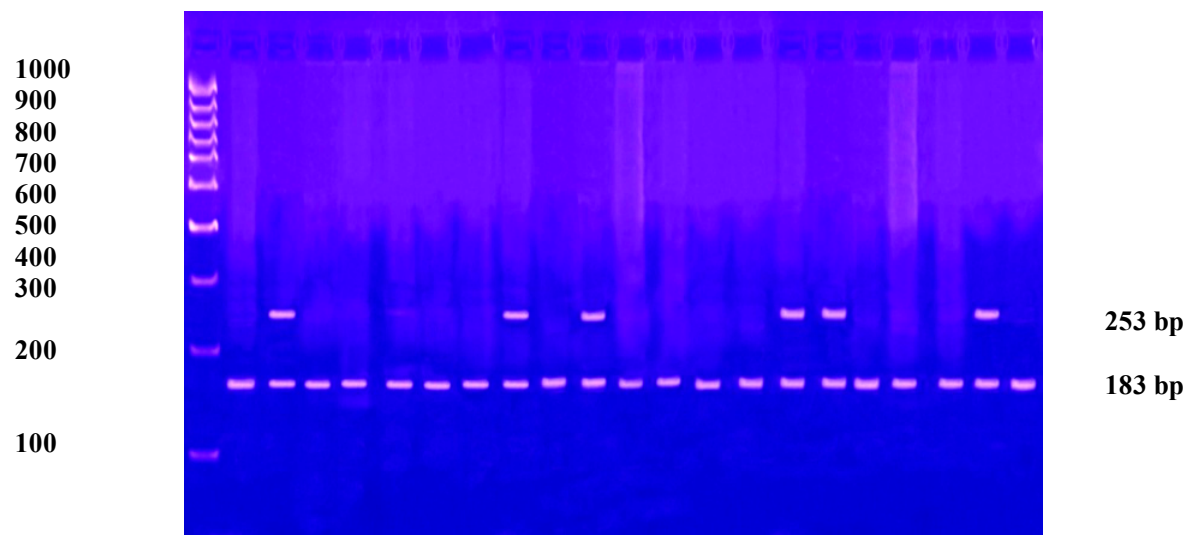

Fig (3): Rheumatoid Arthritis Patients

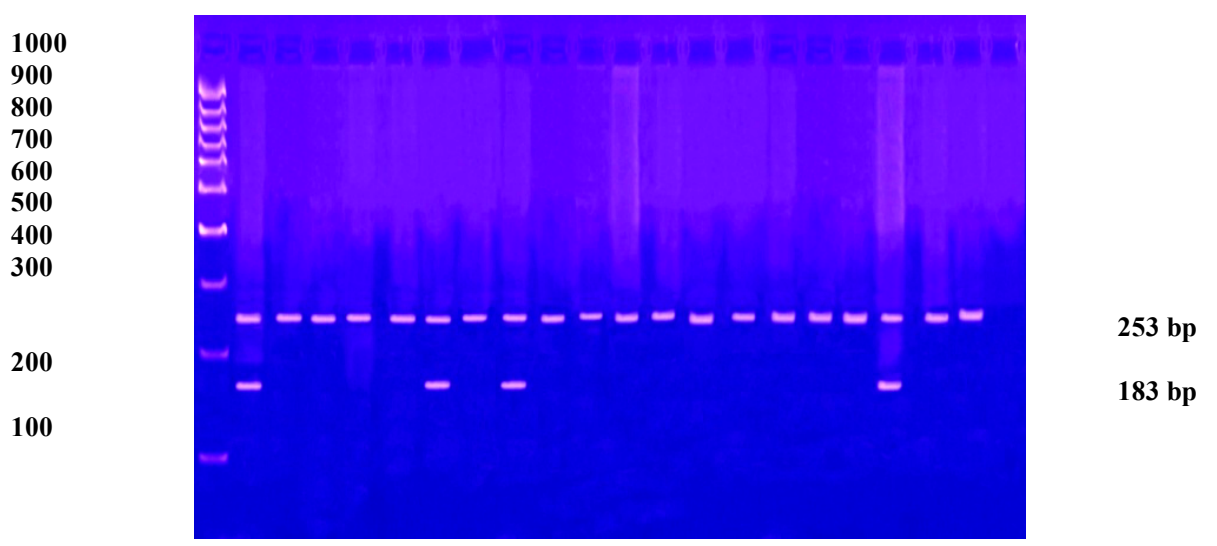

Fig (4): Controls

Fig (3), Fig (4): Agarose gel electrophoresis detection for IL-4 VNTR (intron 3) for RA patients and controls showing lanes of $183 \mathrm{bp}$ fragment for RP1/RP1 homozygous genotype, $253 \mathrm{bp}$ fragment for 


\section{Interleukin-4 Gene polymorphism in Rheumatic Arthriits Patients}

RP2/RP2 genotype and lanes of $183+253$ for RP1/RP2 heterozygous genotype. (100 bp Marker).

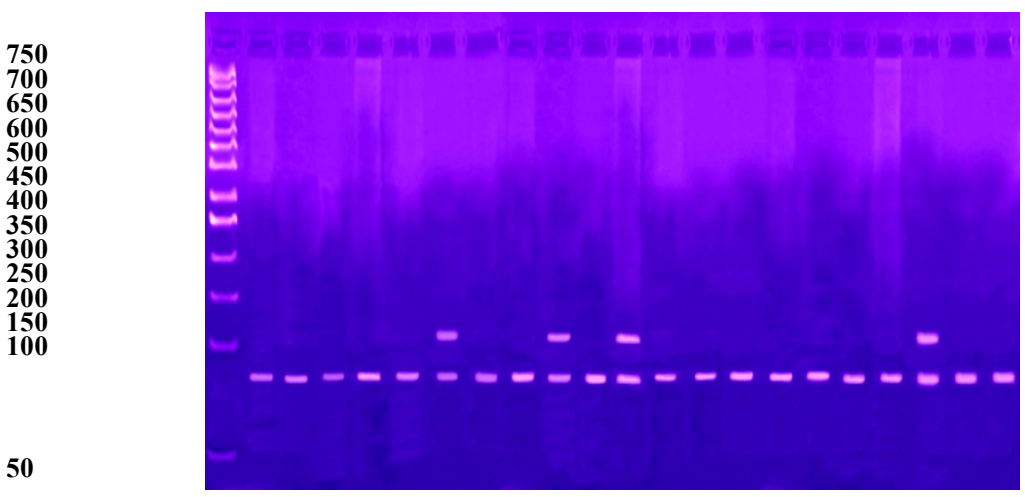

107 bp 89 bp

Fig (5): Rheumatoid Arthritis patients

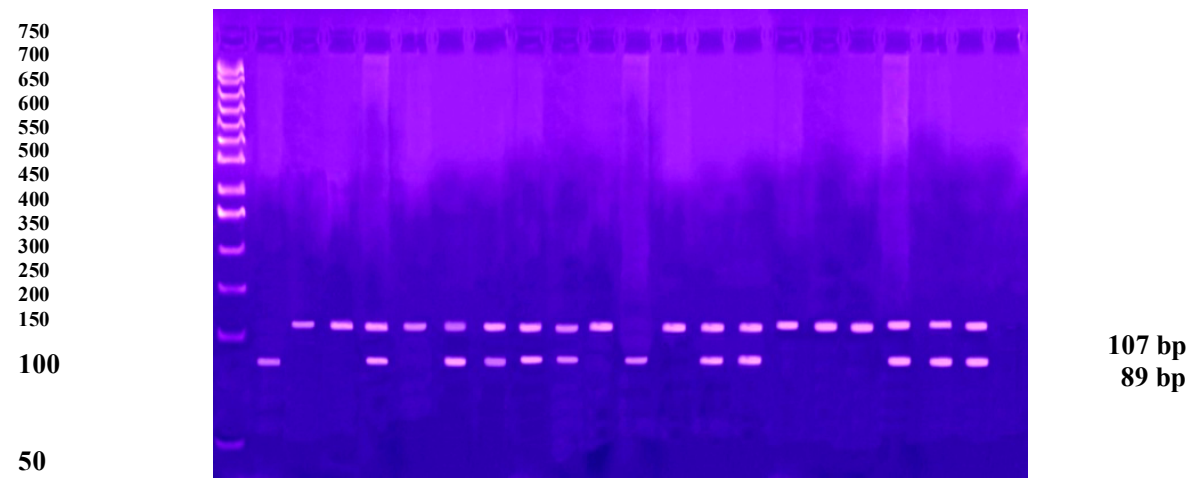

Fig (6): Controls

Fig (5), Fig (6): Agarose gel electrophoresis detection of IL-4 RA position +1902 for RA patients and controls showing lanes of $107 \mathrm{bp}$ fragment for Q576Q homozygous genotype, $89 \mathrm{bp}$ fragment for R576R genotype and lanes of $107+89$ for Q576R heterozygous genotype. (50 bp Marker). 
Faten Z. Mohamed et al.

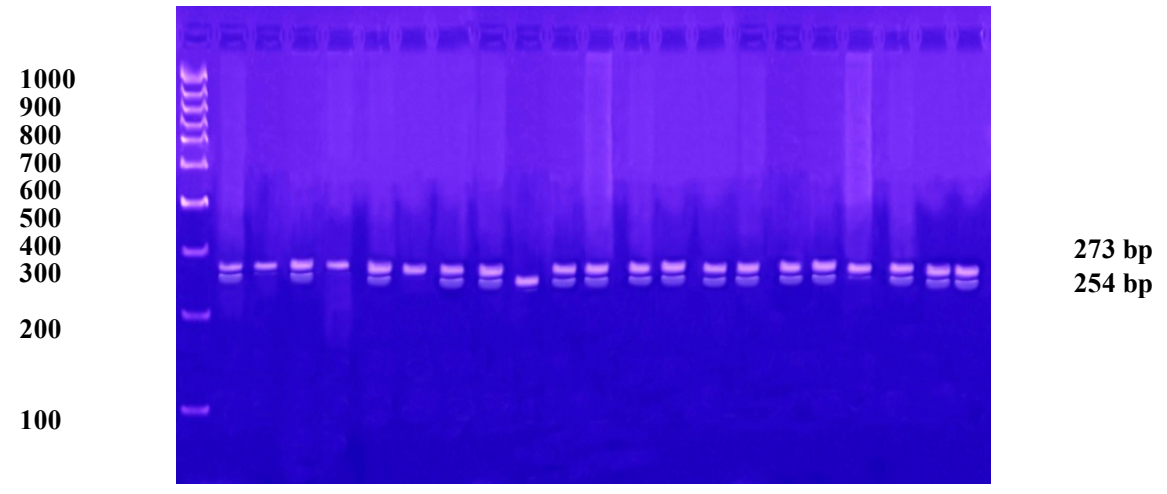

Fig (7): Rheumatoid Arthritis patients

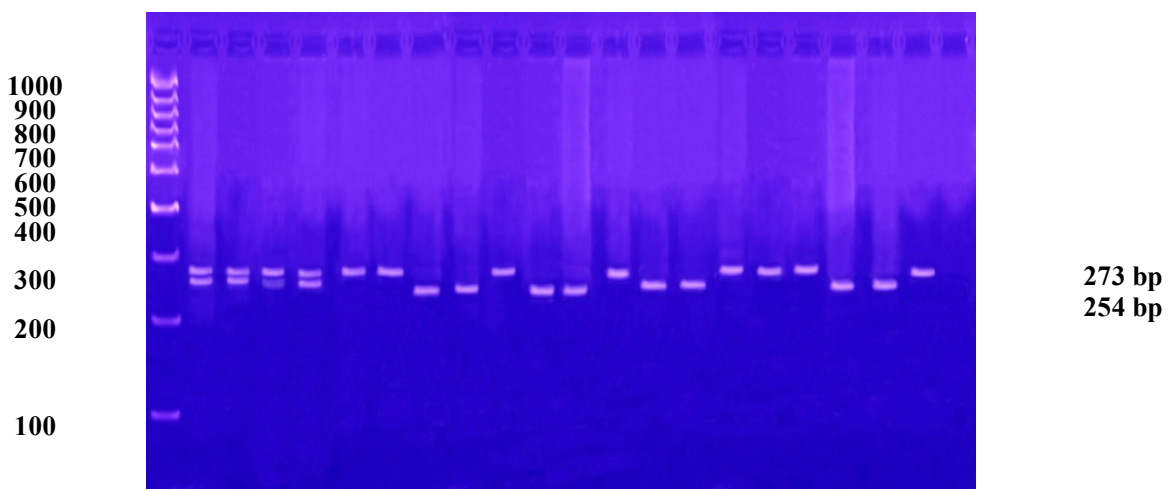

Fig (8): Controls

Fig (7), Fig (8): Agarose gel electrophoresis detection of IL-4 RA (I50V) for RA patients and controls showing lanes of $254 \mathrm{bp}$ fragment for VV homozygous genotype, $273 \mathrm{bp}$ fragment for II genotype and lanes of $254+273$ for IV heterozygous genotype. (100 bp Marker). 
Interleukin-4 Gene polymorphism in Rheumatic Arthriits Patients

Table (1): Distribution of genotypes among the rheumatoid arthritis (RA) patients and healthy control subjects:

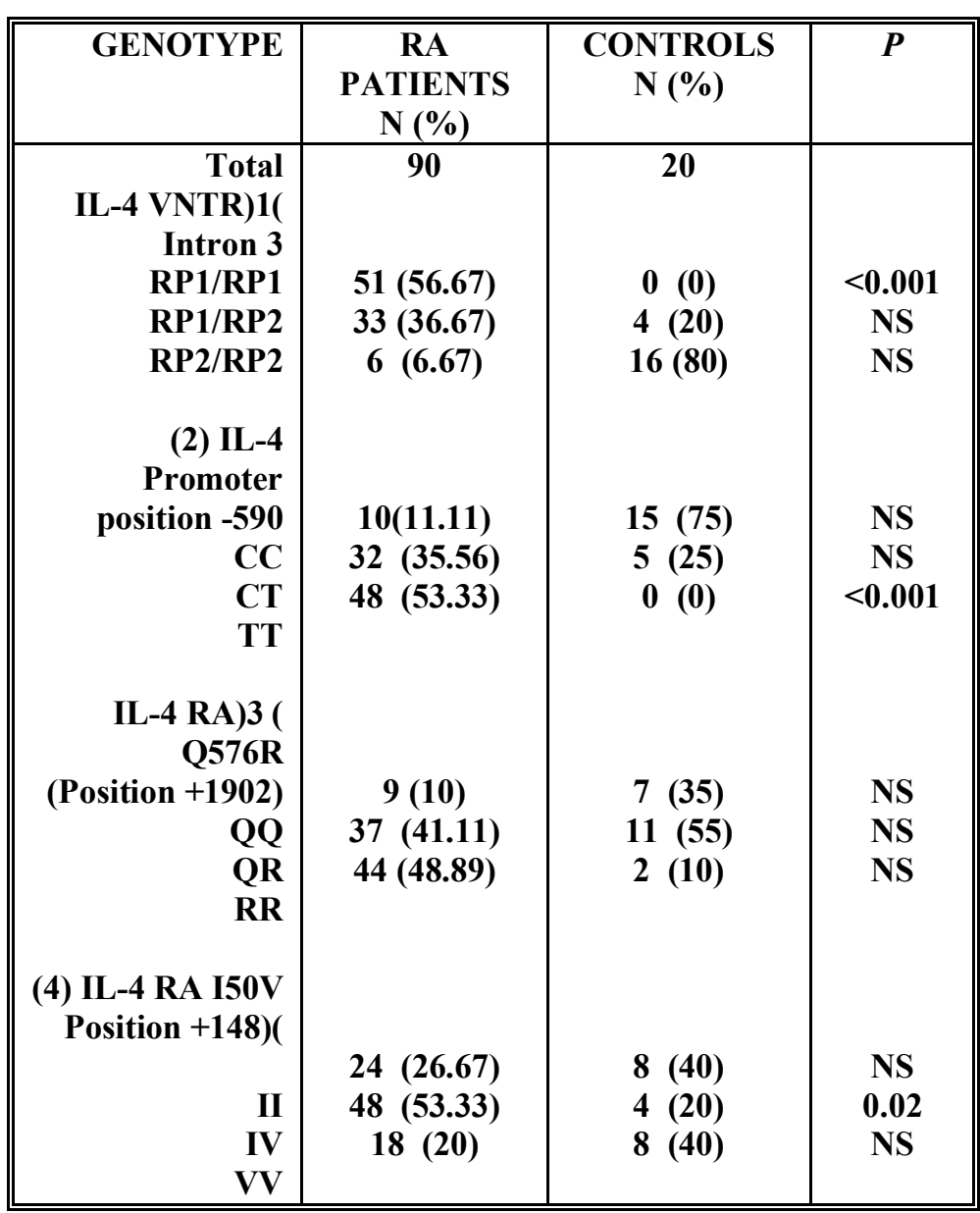

* It is significant when $p<0.05$

RP1/RP1 genotype for IL-4 VNTR is more frequent (56.67\%) than RP1/RP2 and RP2/RP2 genotypes (36.67\% and 6.67\% respectively) among RA patients. 
For IL-4 Promoter single nucleotide polymorphism at position -590 a significantly higher frequency of TT genotype (53.33\%) than CT and CC $(35.56 \%$ and $11.11 \%$ respectively) was observed. While IV genotype is more frequent among RA patients than VV and II genotypes.

Table (2): Comparison of allelic frequencies and carriage rates observed in rheumatoid arthritis patients.

\begin{tabular}{|c|c|c|c|c|c|c|}
\hline \multirow{2}{*}{$\begin{array}{l}\text { GENE, } \\
\text { ALLELE }\end{array}$} & \multicolumn{2}{|c|}{$\begin{array}{c}\text { ALLELIC } \\
\text { FREQUENCY }\end{array}$} & \multicolumn{2}{|c|}{ CARRIAGE RATE } & \multirow[t]{2}{*}{$P$} & \multirow[t]{2}{*}{ OR (95\% CI) } \\
\hline & $\begin{array}{l}\text { RA } \\
\text { No. (\%) }\end{array}$ & $\begin{array}{l}\text { Controls } \\
\text { No. }(\%)\end{array}$ & $\begin{array}{l}\text { RA } \\
\text { No. }(\%)\end{array}$ & $\begin{array}{l}\text { Controls } \\
\text { No. }(\%)\end{array}$ & & \\
\hline $\begin{array}{l}\text { IL-4 } \\
\text { VNTR } \\
\text { RP1 } \\
\text { RP2 }\end{array}$ & $\begin{array}{l}135(76.1) \\
45(25)\end{array}$ & $\begin{array}{l}4(10) \\
36(90)\end{array}$ & $\begin{array}{l}85(94.4) \\
39(93.3)\end{array}$ & $\begin{array}{l}4(20) \\
20(100)\end{array}$ & $\begin{array}{l}0.04 * \\
0.14\end{array}$ & $\begin{array}{l}2.91(0.92-10.23) \\
2.29(0.68-8.54)\end{array}$ \\
\hline $\begin{array}{l}\text { IL-4 } \\
\text { promoter } \\
-590 \mathrm{C} \\
-590 \mathrm{~T}\end{array}$ & $\begin{array}{l}52(28.9) \\
128(71.1)\end{array}$ & $\begin{array}{l}35(87.5) \\
5(12.5)\end{array}$ & $\begin{array}{l}42(46.7) \\
80(88.9)\end{array}$ & $\begin{array}{l}20(100) \\
5(25)\end{array}$ & $\begin{array}{l}0.15 \\
0.03 *\end{array}$ & $\begin{array}{l}2.1(0.68-6.92) \\
2.84(1.0-8.77)\end{array}$ \\
\hline $\begin{array}{l}\text { IL-4 RA } \\
\text { Q576 } \\
\text { R576 }\end{array}$ & $\begin{array}{l}55(30.5) \\
125(69.4)\end{array}$ & $\begin{array}{l}25(62.5) \\
15(37.5)\end{array}$ & $\begin{array}{l}46(51.1) \\
81(90)\end{array}$ & $\begin{array}{l}18(90) \\
13(65)\end{array}$ & $\begin{array}{l}0.39 \\
0.55\end{array}$ & $\begin{array}{l}1.36(0.63-2.94) \\
1.27(0.53-3.04)\end{array}$ \\
\hline $\begin{array}{l}\text { IL-4 RA } \\
\text { I50 } \\
\text { V50 }\end{array}$ & $\begin{array}{l}96(53.3) \\
84(46.7)\end{array}$ & $\begin{array}{l}20(50) \\
20(50)\end{array}$ & $\begin{array}{l}72(80) \\
66(73.3)\end{array}$ & $\begin{array}{l}12(13.3) \\
12(13.3)\end{array}$ & $\begin{array}{l}0.84 \\
0.7\end{array}$ & $\begin{array}{l}1.09(0.42-2.82) \\
1.14(0.55-2.39)\end{array}$ \\
\hline
\end{tabular}

According table (2), it is observed that IL-4 RP1 allele is significantly higher than RP2 allele $(\mathrm{P}=0.04)$ and IL-4 -590 T allele is higher than IL-4 $-590 \mathrm{C}$ allele ( $\mathrm{p}=0.03)$ among the studied RA cases. 
Interleukin-4 Gene polymorphism in Rheumatic Arthriits Patients

Table (3): RF titres in relation to IL-4 genotypes.

\begin{tabular}{|c|c|c||}
\hline $\begin{array}{l}\text { IL-4, IL-4 RA } \\
\text { GENOTYPES }\end{array}$ & RF & P \\
\hline RP1/RP1 & $\mathbf{8 1 . 4 4} \pm 87.64$ & $>0.05$ \\
RP1/RP2 & $76.55 \pm 82.26$ & \\
RP2/RP2 & $74.33 \pm 66.20$ & $<0.001$ \\
\hline CC & $70.29 \pm 9.20$ & \\
CT & $146.00 \pm 16.85$ & $<0.001$ \\
TT & $272.28 \pm 45.57$ & \\
QQ & $\mathbf{1 8 9 . 7 3} \pm 33.15$ & \\
QR & $\mathbf{8 7 . 5 8} \pm 18.57$ & $<0.001$ \\
RR & $47.11 \pm 11.03$ & \\
II & $\mathbf{5 7 . 5 6} \pm 77.11$ & \\
IV & $\mathbf{6 9 . 4 4} \pm 81.99$ & \\
VV & \multicolumn{2}{|}{} \\
\hline
\end{tabular}

High RF titres were seen in IL-4 -590 T allele, IL-4 RA Q576Q allele and IL-4 RA I50 allele carriers. 
Table (4): Association and frequency of the RP1 allele in IL-4 (intron 3 ) and $T$ allele in the IL-4 promoter region in rheumatoid arthritis patients:

\begin{tabular}{||c|c|c|c||}
\hline \hline $\begin{array}{c}\text { CARRIER OF } \\
\text { ALLELE } \\
\text { IL-4RP1/IL-5 }- \\
590 * T\end{array}$ & $\begin{array}{c}\text { PATIENTS } \\
\text { N (\%) }\end{array}$ & $\begin{array}{c}\text { CONTROLS } \\
\text { N (\%) }\end{array}$ & $P$ \\
\hline$+/+$ & & & \\
\hline$+/-$ & $\mathbf{7 5 ( 8 3 . 3 3 )}$ & $\mathbf{0}$ & $\mathbf{0 . 0 0 1}$ \\
\hline$-/+$ & $\mathbf{5 ( 5 . 5 )}$ & $\mathbf{2}$ & NS \\
\hline$-/-$ & $\mathbf{9 ( 1 0 )}$ & $\mathbf{3}$ & NS \\
\hline & $\mathbf{1 ( 1 . 1 1 )}$ & $\mathbf{1 5}$ & NS \\
\hline
\end{tabular}

The simultaneous carriage of these two alleles was observed in 75 patients $(83.33 \%)$ and 5 patients $(5.5 \%)$ carrying IL-4 RP1 allele, 9 patients $(10 \%)$ were carrying IL-4 -590 T allele compared with only one patient carrying no of the two allele indicate a relation ship between the two alleles in RA patients.

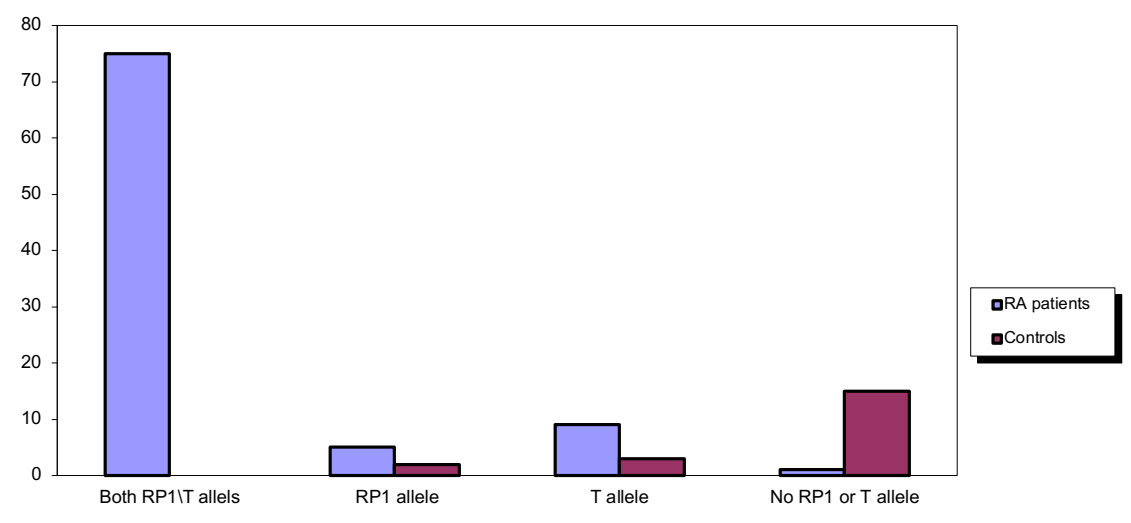

Fig. (9): Relation between IL-4Rp1 allele and IL-4 allele in Ra Patients and Controls

It was observed that most RA patients $(83.33 \%)$ are carrying both IL-4 RP1 and IL-4 -590 T alleles where only one patient wasn't carry any of these two alleles. 
Interleukin-4 Gene polymorphism in Rheumatic Arthriits Patients

\section{DISCUSSION}

Rheumatoid arthritis (RA) is a chronic inflammatory disease characterized by synovial inflammation and pannus formation, which can lead to sever destruction of cartilage and bone ${ }^{\mathbf{( 2 0 )}}$.

The imbalance between pro-inflammatory and anti-inflammatory cytokines is a feature of rheumatoid arthritis (RA).The role of interleukin-4 (IL-4) and its receptor in the pathogenesis of RA is conflicting. The aim of this study was to evaluate the occurrence of IL-4 and IL-4 RA variants in RA patients and their possible contribution to RA susceptibility and/or severity.

A single nucleotide polymorphism (SNP) at position -590 of the promoter region, a 70-bp variable number of tandem repeat (VNTR) in intron 3 for IL-4 and another tow SNPs of Q576R (position +1902), I50 V (position +148) for IL-4 RA were be evaluated.

Our results revealed a significant higher frequency of the IL4 590TT genotype $(\mathrm{P}<0.001)$, a significant higher frequency of the IL4-590T allele (CT and TT genotypes) ( $\mathrm{p}=0.03$, OR 2.84, 95\% CI 1.08.77 ) in RA patients compared with controls.

Other groups have also suggested association of IL-4-590T allele with RA and palindromic rheumatism, and with greater disease activity (Marinou et al, Gregory et al. and Pawlik et al. (21), (22), (23).

In additin, Nuñez et al (24) were reported that IL-4 -590C/T SNP was associated with Type1 Diabetes and Rheumatoid Arthritis.

Our results also showed a significant higher frequency of the IL-4 intron-3 RP1/RP1 genotype ( $<0.001)$ and IL-4 intron-3 RP1 allele (RP1/RP1 and RP1/RP2 genotypes) with RA patients compared with controls ( $\mathrm{P}=0.04$, OR 2.91, 95\% CI 0.92-10.23).

Additionally a significant association between IL4 -590T allele and IL4 VNTR RP1 allele in RA patients only was seen in our population, a result had been reported by Cantagrel et al ${ }^{(16)}$.

Our results show a higher frequency of IL-4 RA I50V genotypes $(\mathrm{P}=0.02)$ than $\mathrm{I} 50 \mathrm{I}$ and $\mathrm{V} 50 \mathrm{~V}$ genotypes among $\mathrm{RA}$ patients compared with controls. This is matched with Susan et al (25). 
Burgos et al. were found an association of IL-4 RA I50V SNPs with rheumatoid nodules in patients with RA ${ }^{(26)}$. Prots et al. were identified the I50V IL4R SNP as a novel genetic marker in RA ${ }^{(27)}$.

High RF titres were related to IL-4-590T, IL-4 RA +1902 A and IL-4 RA I50V $(+148) \mathrm{V}$ allele carriers where the disease is more severe in comparison with IL-4-590T CC, IL-4 RA Q576Q (+1902) and IL-4 RA I50V $(+148)$ VV homozygote in our population.

IgM RF is present in $60-80 \%$ of patients with RA and the titer correlates with disease severity and extraarticular manifestations (28). Patients with high RF titers have articular damage more persistent and severe than those with low titers or negative RF (29).

Our results are in good agreement with Moreno et al ${ }^{(30)}$, they found that IL4 -590TT genotype was significantly more frequent in patients with RA than in controls.

The experiments indicated a 3-fold higher promoter activity of the $\mathrm{T}$ allele and enhanced IgE production ${ }^{(31)}$. It has been shown that C-to-T substitution at position -590 relative to the transcription start site creates the changed core sequence of the nuclear factor of activated T cells (NFAT) contact site and it is possible that there is a linkage disequilibrium between the IL4 -590 T allele and other genes that are important in the control of the immune response ${ }^{(32)}$.

The human gene for IL-4 has been mapped to the $\mathrm{Q}$ arm of chromosome 5 in a cluster of cytokine genes (IL-3, IL-5, IL-9, IL-13, IL-15) ${ }^{(33)}$. Although the-590 $\mathrm{T}$ allele is associated with enhanced promoter activity and probably increased IL-4 production, nevertheless the linkage disequilibrium with other genes that are responsible for the transcriptional activation of proinflammatory factors may cause the increased susceptibility to RA and greater disease severity ${ }^{(34)}$.

Susan et al. were indicated that an inherited polymorphisms of the IL-4R controls the ability of the human immune system to regulate the magnitude of IL-17 production. However, in established RA, this pattern may be altered, possibly due to secondary effects of both RA itself as well as immunomodulatory medications. Ineffective control of Th17 immune responses is a potential mechanism to explain why IL-4R is an important severity gene in RA. 


\section{CONCULSION}

Evidence is accumulating that IL-4 has a complex function in the development of innate and adaptive immunity and might play an important role in the preclinical or early phases of RA. Our results showing an association of IL4 -590T, IL-4RP1 alleles and IL-4 RA I50V genotype with RA susceptibility. The IL-4-590T, IL-4 RA V50 and IL-4 RA Q576 allele with RA severity.

\section{ACKNOWLEDGEMENT}

This study was funded with the support of academic research in Zagazig University Projects, Zagazig University Post Graduate \& Research Affairs.

\section{REFERENCES}

1. Firestein GS. . Etiology and pathogenesis of rheumatoid arthritis. In (2005): Harris ED, Budd RC, Genovese MC, Firestein GS, Sargent JS, Sledge CB, eds. Kelley's Textbook of Rheumatology. 7th ed. Philadelphia, Pa: Saunders Elsevier; chap 65 .

2. O'Dell JR. Rheumatoid arthritis In (2007): Goldman L, Ausiello D, eds. Cecil Medicine. 23rd ed. Philadelphia, Pa: Saunders Elsevier; chap 285

3. Smith JB, Haynes MK (2002): Rheumatoid arthritis. A molecular understanding. Ann Intern Med 36: 908-22.

4. Pociot F, McDermott MF (2002): Genetics of type 1 diabetes mellitus, Genes Immun 3:235-49. 
5. Morita Y, Yamamura M, Kawashima $M$, et al. (2001): Differential in vitro effects of IL-4, IL-10, and IL-13 on proinflamatory cytokine production and fibroblast proliferation in rheumatoid synovium. Rheumatol Int 20:4954.

6. Pearce SH, Merriman TR (2006): Genetic progress towards the molecular basis of autoimmunity. Trends Mol Med; 12:9098.

7. Lee SG, Kim BS, Kim JH, Lee SY, Choi SO, Shim JY, et al.(2009): Gene-gene interaction between interleukin- 4 and interleukin-4 receptor alpha in Korean children with asthma. Clin Exp Allergy 39: 1202-1208.

8. Cui T, Wang L, Wu J, Hu L, Xie J (2009): Polymorphisms of IL-4, IL-4 R alpha and AICDA genes in rheumatoid arthritis. J Huazhong Univ SCi Technology Med Sci 29: 134-137.

9. Miloux B, Laurent P, Bonnin O, Lupker J, Caput D, Vita N, et al (2008): Cloning of the human IL-13R alpha1 chain and reconstitution with the IL4R alpha of a functional IL-4/IL-13 receptor complex. FEBS Lett 411: 163-166.

10. Rosenwasser LJ, Borish $\mathbf{L}$ et al. (2005): Genetics of atopy and asthma: the rationale behind promoter-based candidate gene studies (IL-4 and IL-10). Am J Respir Crit Care Med ,163: 5152-5155.1-

11. N.Buchs, T.Silvestri, F.S. di Giovine, M.Chabuad, E.Vannier,G.W. Duff and P.Miossecue (2000): IL-4 VNTR gene polymorphism in chronic polyarthritis. Rheumatology 30:1126-1131.

12. Chatterjee A, Rathore A, and Dhole TN.(2009): Association of IL-4 $589 \mathrm{C} / \mathrm{T}$ Promoter and IL-4Ra I50V Receptor Polymorphism With Susceptibility to HIV-1 Infection in North Indians Journal of Medical Virology; 81:959-965 
13. Chen, H., Wilkins, L. M., Aziz, N., Cannings et al. (2006): Single nucleotide polymorphisms in the human interleukin-4 gene affect transcription according to haplotype context. Hum Mol Genet ; 15: 519-529.

14. Franjkovic I, Gessner A, Konig I, Kissel K, Bohnert A, Hartung A, et al. (2005): Effect of common atopyassociated amino acid substitutions in the IL-4 receptor alpha chain on IL-4 induced phenotypes. Immunogenetics . 56: 808-817.

15. Amett FC,Edworthy SM, Bloch DA, McShane DJ, Pries JF, Cooper NS et al.(1988): The American Rheumatism Association 1987 revised criteria for the classification of rheumatoid arthritis. Arthritis Rheum. 31:315-24.

16. Cantagrel A, Navaux F, Loubet-Lescoulié P, et al. (1999): Interleukin-1ß, interleukin-1 receptor antagonist, interleukin4 and interleukin-10 gene polymorphisms. Relationship to occurrence and severity of rheumatoid arthritis. Arthritis Rheum;42:1093-100

17. Noguchi E, Shibasaki M, Arinami T et al. (1999): No association between atopy/asthma and the ILe50Val polymorphism of IL-4 receptor. Am J Respir Crit Care Med; 160:342-345.

18. Sandford AJ, Chagani T, Zhu S, et al (2000): Polymorphisms in the IL4, IL4RA, and FCERIB genes and asthma severity. J Allergy Clin Immunol,106:135-140.

19. Levesque, R. (2007): SPSS Programming and Data Management: A Guide for SPSS and SAS Users, Fourth Edition. SPSS Inc., Chicago Ill.

20. Alivernini S, Fedele AL, Cuoghi I, et al. (2008): Citrullination: the loss of tolerance and development of autoimmunity in rheumatoid arthritis. Reumatismo. 60 (2): 85-94.

21. Marinou et al 1-Deichmann K, Bardutsky J et al. (1997): Common polymorphisms in the coding part of the IL-4 receptor gene. Biochem Biophys Res Commun. 231:696-7. 
22. Gregory GD, Raju SS, Winandy S, Brown MA.(2006): Mast cell IL-4 expression is regulated by Ikaros and influences encephalitogenic Th1 responses in EAE. J Clin Invest 116:1327-36.

23. Pawlik A, Wrzesniewska J, Florezak M, Ostanek L, Gawronska B, Herczynska M. (2005): The -590 IL-4 promoter polymorphism in patients with rheumatoid arthritis. Rheumatol Int. 26:48-51.

24. Concepción Nuñez \& Jose Luis Santiago \& Jezabel Varadé et al. (2008): IL4 in the 5q31 context: association studies of type 1 diabetes and rheumatoid arthritis in the Spanish population. Immunogenetics. 60:19-23

25. Suzan K wallis, Laura A Cooney, Judith Endres et al. (2011): A polymorphism in Interleukin-4 Receptor affects the ability to regulate Th17 cells.Arthritis research and therapy. 13:R15.

26. Paula I Burgos, Zenoria L Causey, Ashutosh Tamhane and James M Kelley et al.(2010): Association of $I L 4 R$ single-nucleotide polymorphisms with rheumatoid nodules in African Americans with rheumatoid arthritis. Arthritis Research \& Therapy. 12:R75.

27. Prots, I., Skapenko, A., Wendler, J. and Mattyasovszky, S. et al.(2006): Association of the $I L 4 R$ single-nucleotide polymorphism I50V with rapidly erosive rheumatoid arthritis. Arthritis \& Rheumatism. 54: 14911500 .

28. Saaibi DL. (2004): Factor reumatoideo y otros auotanticuerpos en artritis reumatoide. In: Ramírez LA, Anaya J-M, editors. Artritis reumatoide. 2 ed. Bogotá: Editorial Edimeco SA;117-25.

29. Bukhari M, Lunt M, Harrison BJ, Scott DGI, Symmons DPM, Silman AJ. (2002): Rheumatoid factor is the major predictor of increasing severity of radiographic erosions in rheumatoid arthritis. Arthritis Rheum. 46:906- 12. 
30. Olga MORENO, Clara Isabel, DiegO Luis and William OTERO et al. (2007): Polymorphisms in the IL4 and IL4RA Genes in Colombian Patients with Rheumatoid Arthritis. Journal of rheumatology.127-35.

31. Suzuki I, Yamaguchi E, Hizawa N, Itoh A, Kawakami Y (2007) :A new polymorphism in the 5 ' flanking region of the human interleukin (IL)-4 gene. Immunogenetics. , 58: 738739.

32. 32-Franjkovic I, Gessner A, Konig I, Kissel K, Bohnert A, Hartung A, et al. (2005): Effect of common atopyassociated amino acid substitutions in the IL-4 receptor alpha chain on IL-4 induced phenotypes. Immunogenetics, 56: 808817.

33. Palmer LJ, Daniels SE, Rye PJ, Gibson NA, Tay GK, Cookson WO, et al. (2004): Linkage of chromosome $5 q$ and 11q gene markers to asthma-associated quantitative traits in Australian children. Am J Respire Crit Care Med;164: 18251830.

34. Basehore MJ, Howard TD, Lange LA, Moore WC, Hawkins GA, Marshik PL, et al.(2004) :A comprehensive evaluation of IL4 variants in ethnically diverse populations: association of total serum IgE levels and asthma in white subjects. J Allergy Clin Immunol , 114: 80-87. 